Pesq. Vet. Bras. 35(6):557-561, junho 2015

DOI: $10.1590 / \mathrm{S} 0100-736 \mathrm{X} 2015000600012$

\title{
Outbreaks of canid herpesvirus 1 disease in puppies in southern Brazil ${ }^{1}$
}

\author{
Juliana F. Cargnelutti², Eduardo K. Masuda ${ }^{3}$, Mariana G. Neuls ${ }^{4}$, Rudi Weiblen ${ }^{2}$ \\ and Eduardo F. Flores ${ }^{2 *}$
}

\begin{abstract}
Cargnelutti J.F., Masuda E.K., Neuls M.G., Weiblen R. \& Flores E.F. 2015. Outbreaks of canid herpesvirus 1 disease in puppies in southern Brazil. Pesquisa Veterinária Brasileira 35(6):557-561. Setor de Virologia, Departamento de Medicina Veterinária Preventiva, Universidade Federal de Santa Maria, Av. Roraima 1000, Santa Maria, RS 97105-900, Brazil. E-mail: eduardofurtadoflores@gmail.com

Canid herpesvirus 1 (CHV-1) is a widespread pathogen of dogs and produces infertility, abortions and severe systemic disease in young puppies. Clinical data indicate the circulation of CHV-1 among Brazilian dogs yet definitive diagnosis has rarely been accomplished. This article describes the clinicopathological findings of four independent cases/outbreaks of neonatal disease by CHV-1 in Bulldog puppies followed by virus identification and genetic characterization. Three events occurred in a kennel holding dogs of different breeds at reproductive age (March 2013, October 2013 and April 2014). Puppies from three French or English Bulldog litters, aging 9 to 30 days were affected, presenting dyspnea, agonic breathing, pale mucous, abdominal pain and tension, evolving to death within about 24 hours. At necropsy, the puppies presented necrohemorrhagic hepatitis, multifocal and moderate necrohemorrhagic nephritis and fibrinonecrotic interstitial pneumonia. Virus isolation was positive in clinical specimens from one litter and CHV-1 DNA was detected by PCR in tissues from all four cases. Virus-neutralizing assays with samples of the affected kennel revealed 9/12 adult animals with high antibody titers to CHV-1. Nucleotide sequencing of glycoprotein B, C and D genes revealed $99-100 \%$ of identity among the viruses and with CHV-1 sequences available in GenBank. Phylogenetic analyses of gC sequences showed a segregation of the samples, even among three isolates from the same kennel. These findings support CHV-1 infection as the cause of disease and death in these dog litters, reinforcing the need for correct etiologic diagnosis, prevention and immunization against CHV-1 in dogs from Southern Brazil.
\end{abstract}

INDEX-TERMS: Canid herpesvirus 1, CHV-1, diagnosis, dogs, glycoproteins and pathological findings.

RESUMO.- [Surtos de doença por herpesvírus canino 1 em filhotes de cães no sul do Brasil.] 0 herpesvírus canino (CHV-1) é um patógeno de cães que possui distribuição mundial e que causa infertilidade, abortos e doença

\footnotetext{
${ }^{1}$ Received on October 31, 2014.

Accepted for publication on March 16, 2015.

${ }^{2}$ Setor de Virologia, Departamento de Medicina Veterinária Preventiva, Universidade Federal de Santa Maria (UFSM), Av. Roraima 1000, Santa Maria, RS 97105-900, Brazil. *Corresponding author: eduardofurtadoflores@ gmail.com

${ }^{3}$ Axys Análises Diagnóstico Veterinário e Consultoria, Av. Salvador Leão 147, Salas 101 and 202, Porto Alegre, RS 91130-700, Brazil.

${ }^{4}$ Fertivida - Clínica Veterinária, Rua Lucas de Oliveira 2689, Porto Alegre, RS 90460-001.
}

sistêmica severa em filhotes de cães. Achados clínicos tem indicado a circulação do CHV-1 em cães no Brasil, embora o diagnóstico definitivo seja raramente determinado. Este artigo descreve os achados clinicopatológicos de quatro casos/surtos independentes de morte neonatal de filhotes de cães da raça Bulldog causados pelo CHV-1, a identificação e a caracterização genética do vírus. Três eventos ocorreram no mesmo canil que abriga animais de diferentes raças em idade reprodutiva (março de 2013, outubro de 2013 e abril de 2014). Filhotes de três ninhadas de Bulldog Francês e/ou Inglês, com idade de 9 a 30 dias, foram afetados e apresentaram dispneia, respiração agônica, mucosas pálidas, dor e tensão abdominal, que evoluíram para morte dos cães dentro de, aproximadamente, 24 horas. Na necrop- 
sia foram observados hepatite necro-hemorrágica, nefrite necro-hemorrágica multifocal e moderada e pneumonia intersticial fibrinonecrótica. $\mathrm{O}$ isolamento viral foi positivo em amostras clínicas de um filhote e DNA de CHV-1 foi detectado por PCR em tecidos de filhotes de todos os surtos. Teste de soroneutralização com amostras de soro de cães provenientes do canil afetado revelaram que nove de 12 animais adultos possuíam altos títulos de anticorpos para o CHV-1. Sequenciamento de nucleotídeos do gene das glicoproteínas B, C e D revelaram 99-100\% de identidade entre as amostras e com as sequências de CHV-1 disponíveis no GenBank. A análise filogenética baseada na sequência do gene da glicoproteína C mostrou uma segregação das amostras, mesmo entre os três isolados de vírus provenientes do mesmo canil. Esses achados demonstram que o CHV1 é a causa da doença e da morte dos filhotes, reforçando a necessidade do correto diagnóstico etiológico e a implementação de medidas de prevenção e imunização contra o CHV-1 em cães no sul do Brasil.

TERMOS DE INDEXAÇÃO: Herpesvírus canino tipo 1, CHV1, diagnóstico, cães, glicoproteínas e lesões.

\section{INTRODUCTION}

Canid herpesvirus 1 (CHV-1) belongs to family Herpesviridae, subfamily Alphaherpesvirinae, genus Varicellovirus (ICTV, 2015) and it is associated with a variety of clinical manifestations in dogs including neonatal deaths, respiratory, ocular, and reproductive disorders (Evermann et al. 2011). Like other alphaherpesviruses, CHV-1 establishes latent infections in neural and non neural tissues after acute infection and can be reactivated in stressful and immunosuppressive situations (Miyoshi et al. 1999).

The outcome and clinical manifestations of CHV-1 infection in dogs are associated with several risk factors, including age, breeding and kennel cough (Ronsse et al. 2004). Adult dogs infected with CHV-1 usually develop a mild respiratory disease, frequently associated with Parainfluenza virus and Bordetella bronchiseptica infection (Decaro et al. 2008, Evermann et al. 2011). The most important disorders associated with CHV-1 infection, however, generally occur in pregnant bitches and in young puppies. Systemic viremia in pregnant females may result in transplacentary CHV-1 transmission and fetal infection, leading to fetal deaths, abortion, mummification, infertility and the birth of weak puppies (Hashimoto et al. 1983, Anvik 1991, Decaro et al. 2008, Evermann et al. 2011). In neonates infected in utero or during the birth, the mortality usually approaches $100 \%$ due to a multisystemic necrohemorrhagic disease (Ronsse et al. 2005, Decaro et al. 2008, Evermann et al. 2011). The age of the puppies at the time of primary infection is determinant to the outcome of the disease and the clinical signs are usually more severe in neonates (Decaro et al. 2008). Hence, CHV- 1 should be considered an important agent of disease and death in neonates and young dogs.

Cases of disease clinically compatible with CHV-1 infection have been frequently reported by veterinarians in Brazil yet a definitive diagnosis is rarely reached. Likewise, serological studies and/or virus identification have not been conducted to date, is spite of this clinical rele- vance. To date, only few reports were described in Brazil: a pathological description of neonatal death of two litters (Oliveira et al. 2009); a case of virus isolation and molecular identification of CHV-1 in a puppy with neonatal death (Kurissio et al. 2012) and a clinicopathological description of neonatal death in dogs with 10 days-old (Ávila et al. 2011). As no vaccine is commercially available in Brazil, CHV-1 infection of bitches and neonate puppies seem to occur endemically and, as such, have acquired relative importance for dog breeders and domestic dog owners in past years. This report describes four cases/outbreaks of CHV-1 infection in Bulldog puppies and molecular identification of the agent. We hope our report contribute for the understanding of CHV-1 biology and, most importantly, to call attention to and help veterinarians in recognizing such cases.

\section{MATERIALS AND METHODS}

\section{Outbreak description}

The four cases of CHV-1 infection occurred in Bulldog litters in Porto Alegre, Rio Grande do Sul. Three occurred from March to October 2013 (fall to spring) and the later occurred in April 2014. The main epidemiological and clinical findings are described below:

Case 1 (SV822/13). Two 9 to 15-day-old puppies out of a litter of eight English Bulldogs presented severe dyspnea, pale mucous, abdominal pain and tension, with a fast evolution to death (approx. $24 \mathrm{~h}$ ). After birth, the bitch developed a severe mastitis that hampered breast-feeding.

Case 2 (SV 823/13). Four 22-day-old litter of English Bulldog puppies developed respiratory agony and pulmonary edema that evolved to death in a few hours.

Case 3 (SV1110/13). A 30-day-old puppy of a litter of French Bulldogs presented nasal discharge, abdominal pustules and neurological signs, characterized by ataxia and incoordination. The clinical course evolved to death in approximately $24 \mathrm{~h}$.

Case 4 (SV242/14). Two 23-day-old puppies of a litter of six English Bulldogs developed abdominal pain and showed pale mucosae, with fast evolution to death $(24 \mathrm{~h})$. The bitch was seronegative to CHV-1 when introduced in the kennel, immediately before the pregnancy.

Case 1, 3 and 4 occurred in the same kennel, which holds approximately one hundred male and female dogs at reproductive age, but in different occasions (SV822/13 occurred in October 2013; SV1110/13 in March 2013, and SV242/14 in April 2014).

\section{Pathologic analyses}

Animals from all reported cases were submitted to necropsy and tissue samples (kidney, lung and liver) were collected for histopathology and virology diagnosis. For histopathology, samples were fixed in $10 \%$ buffered formalin and processed for routine histopathological examination. The slides were stained using hematoxylin and eosin (H \& E) standard protocol.

\section{Virus isolation}

For virus isolation, tissue fragments (kidney, lung and liver) were grinded, homogenized and resuspended to $10 \%$ (weight/ volume) in culture medium. After low speed centrifugation, the supernatants were inoculated onto monolayers of primary canine kidney cells, stored at $32^{\circ} \mathrm{C}$ with $5 \%$ of $\mathrm{CO}_{2}$ and monitored for cytopathic effect (cpe) during three passages of five days each before considering negative for virus. 


\section{Virus-neutralization}

Thirteen serum samples collected from dogs and bitches of different breeds at reproductive age from the kennel (cases 1, 3 and 4) were submitted to a standard virus-neutralization (VN). VN assays were performed in 96-well plates, testing two-fold dilutions of sera against a fixed dose of virus (100-200 $\mathrm{TCID}_{50} /$ well) and MDCK cells as indicators. The CHV-1 used in VN assays was kindly provided by Dr. João Pessoa Araújo Júnior (Unesp, Pirassununga, $\mathrm{SP})$. VN readings were performed after five days of incubation at $32{ }^{\circ} \mathrm{C}$ and VN titers were considered as the reciprocal of highest dilution of sera that prevented the production of cpe. Sera from a dog naturally infected with $\mathrm{CHV}-1$ and from a seronegative dog were used as positive and negative controls, respectively.

\section{Molecular analysis}

Total DNA was extracted from tissue samples (pool of kidney, liver and lung) using DNAzol Reagent ${ }^{\mathrm{a}}$ and submitted to PCR for CHV-1 glycoprotein B gene (gB), using the primers and conditions previously described (Ronsse et al. 2005). DNA extracted from the liver of a dog infected with CHV-1 (SV435/08) (Oliveira et al. 2009) was used as positive control. Additionally, PCR to glycoproteins $\mathrm{C}$ and $\mathrm{D}$ (gC and gD; Table 1) were performed. The amplicons were purified using the PureLink PCR kit according to the manufacturer's instructions and submitted to nucleotide sequencing in an automatic sequencer ABI-PRISM 3100 Genetic Analyzer armed with $50 \mathrm{~cm}$ capillaries and POP6 polymer (Applied Biosystems, Carlsbad, CA, USA). The obtained sequences were analyzed by the Staden package (Staden 1996) and aligned using the Bio-
Table 1. Primers and PCR conditions used to amplified fragments of glycoproteins C and D of Canid Herpesvirus-1

\begin{tabular}{|c|c|c|c|c|}
\hline Gene & Primer sequence $\left(5^{\prime}-3^{\prime}\right)$ & $\begin{array}{l}\text { Nucleotide } \\
\text { positions }\end{array}$ & $\begin{array}{l}\text { Amplicon } \\
\text { size (bp) }\end{array}$ & PCR conditions \\
\hline $\mathrm{gC}$ & $\begin{array}{l}\text { F: CGGCATCTACATCCAAAC } \\
\text { R: GACCGTCAATCCATACAC }\end{array}$ & $\begin{array}{c}\text { Based on gC - } \\
\text { AF361074 } \\
65-82 \\
832-815\end{array}$ & 768 & $\begin{array}{c}95^{\circ} \mathrm{C}-5 \mathrm{~min}, 30 \mathrm{x} \\
\left(95^{\circ} \mathrm{C}-1 \mathrm{~min},\right. \\
50^{\circ} \mathrm{C}-1 \mathrm{~min}, \\
\left.72^{\circ} \mathrm{C}-1 \mathrm{~min}\right) \\
72^{\circ} \mathrm{C}-7 \mathrm{~min}\end{array}$ \\
\hline gD & $\begin{array}{l}\text { F: CTTCTACTGACCCATGTG } \\
\text { R: TGGCCTCGATGGTAATTC }\end{array}$ & $\begin{array}{c}\text { Based on gD - } \\
\text { AF361076 } \\
3614-3631 \\
4260-4243\end{array}$ & 647 & $\begin{array}{c}95^{\circ} \mathrm{C}-5 \mathrm{~min}, 30 \mathrm{x} \\
\left(95^{\circ} \mathrm{C}-1 \mathrm{~min},\right. \\
47.5^{\circ} \mathrm{C}-1 \mathrm{~min}, \\
\left.72^{\circ} \mathrm{C}-1 \mathrm{~min}\right) \\
72^{\circ} \mathrm{C}-7 \mathrm{~min}\end{array}$ \\
\hline
\end{tabular}

Edit Sequence Alignment Editor Software suite, version 7.0.5.3 (Hall 1999) and compared with other CHV-1 sequences deposited in GenBank. To building the phylogenetic tree, based on sequences of gC gene, it was used the Neighbor-Joining method with 2000 bootstrap replicates implemented by MEGA5.0 (Tamura et al. 2011), based on Tamura 3- parameters model.

\section{RESULTS AND DISCUSSION}

At necropsy, all puppies had severe necrohemorrhagic disease, characterized by multifocal to aleatory petechia in liver and kidneys. In the lungs had severe edema and hemorrhage. At histopathologic examination, there were ne-

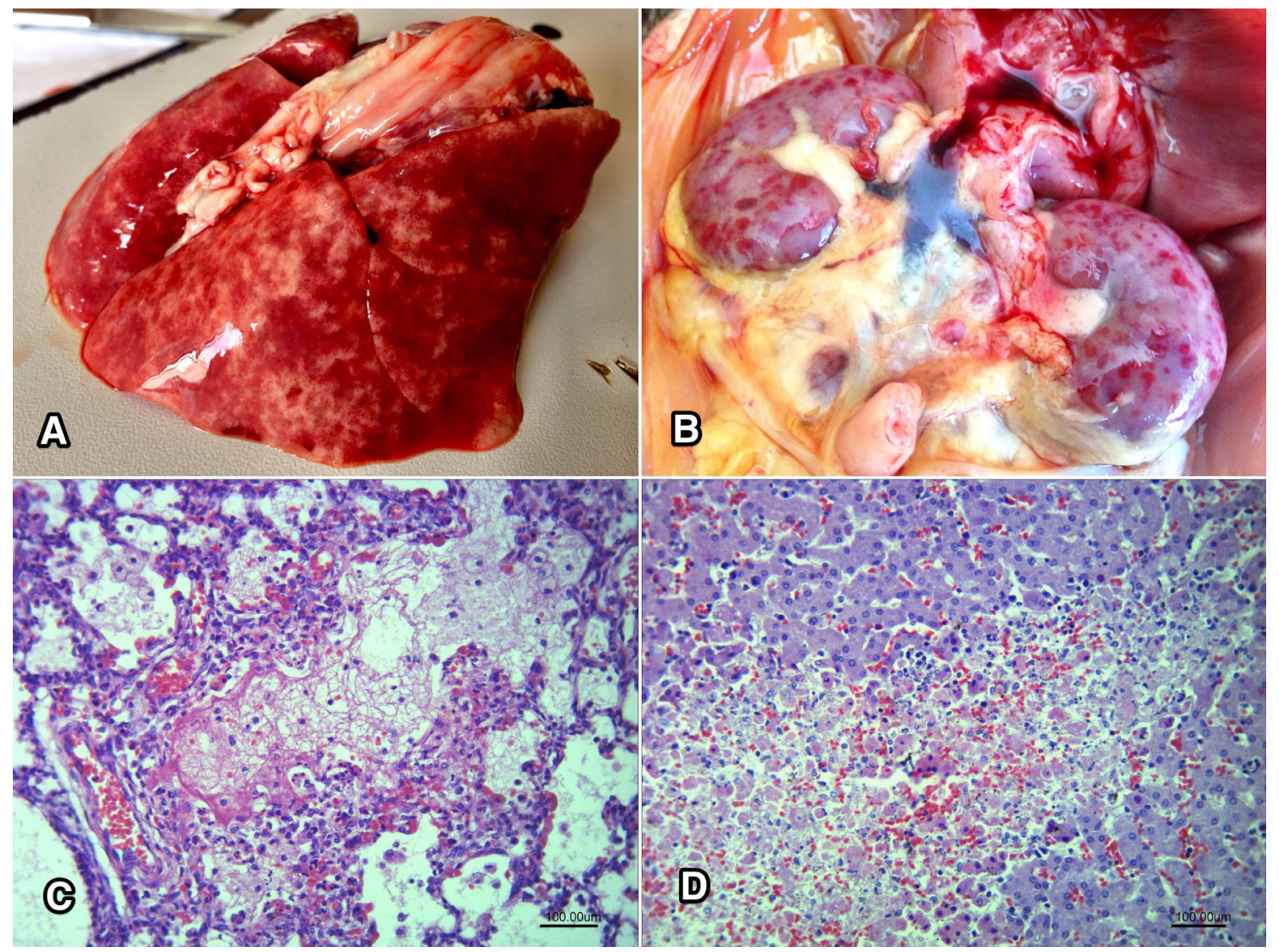

Fig.1. (A) Pulmonary lobes with severe edema and hemorrhage. (B) Aleatory foci of hemorrhage (petechia) over the renal cortex. (C) Multiple alveoli are necrotic and filled by fibrinous plaques and mild to moderate neutrophilic and histiocytic inflammatory infiltrate. (D) Severe necrosis of hepatocytes with Councilmann-like bodies and moderate hemorrhage. (C, D) Hematoxylin and eosin. Bar $=100.00 \mu \mathrm{m}$. 


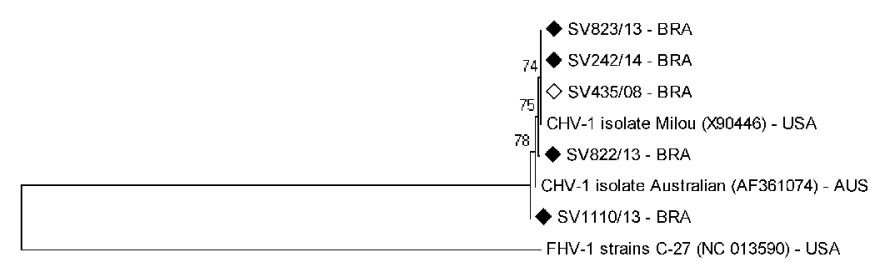

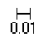

Fig.2. Phylogenetic tree based on the nucleotide sequences of glycoprotein $\mathrm{C}$ gene of Canid Herpesvirus 1 . The tree was constructed using the Neigbohr-Joining method with 2,000 bootstrap replicates based on Tamura-3 parameters model and implemented by MEGA 5.0. Values $>70 \%$ are shown. CHV1 samples recovered of the four reported cases (SV822/13, SV823/13, SV1110/13 and SV242/14) are identified with a black diamond. Brazilian CHV-1 sample from other case (Oliveira et al. 2009) is identified with a white diamond.

crohemorrhagic hepatitis, multifocal and moderate necrohemorrhagic nephritis (Fig.1A), and fibrinonecrotic and hemorrhagic interstitial pneumonia (Fig.1B). Intranuclear herpesviral viral corpuscles were not observed in all cases, yet the findings in all target organs were characteristic of CHV-1 infection in neonates (Love \& Huxtable 1976, Oliveira et al. 2009). No distemper virus-associated lesions were observed in any case (differential diagnosis).

Cells inoculated with tissue homogenates of case SV822/13 developed typical herpesvirus cpe after $48 \mathrm{~h}$ of incubation, characterized by cell rounding and detaching from the monolayer. The other samples remained negative for cpe after three passages. Since three cases occurred in the same kennel (SV822/13, SV1110/13 and SV242/14) at different times, we tested serum samples obtained in this kennel for CHV-1 antibodies. Thirteen serum samples collected from dogs and bitches of different breeds at reproductive age were submitted to a standard virus-neutralization (VN). Nine dogs presented antibodies to CHV-1 in titers ranging from 16 to 128 . These data demonstrate previous exposure to the virus since these dogs had no history of CHV-1 vaccination and, in addition, indicate that CHV-1 infection is probably endemic in the kennel. As positive serology for CHV-1- and for other alphaherpesviruses as well - indicate the condition of latent carrier, the serological findings undercovered an important epidemiological situation in this kennel since seropositive animals may occasionally reactivate and transmit the virus. Thus, the virus is probably perpetuated in the kennel through periodic episodes of reactivation and transmission.

Total DNA was extracted from pools of kidney, liver and lung, were submitted to PCR to gB gene and a band of approximately $443 \mathrm{bp}$ - corresponding to the expected amplicon for CHV-1 - was detected in DNA extracted from tissue samples of all investigated cases (SV822/13, SV823/13, SV1110/13 and SV242/14). Additionally, PCR to glycoproteins $\mathrm{C}$ and $\mathrm{D}$ (gC and gD; Table 1 ) were performed to confirm the etiologic agent and to analyze gene sequences.

The nucleotide identity of genes $\mathrm{gB}, \mathrm{gC}, \mathrm{gD}$ from the samples and CHV-1 sequences available in GenBank ranged from 99 to $100 \%$, and the lower identities were observed in $\mathrm{gB}$ and $\mathrm{gC}$ sequences. The gC sequence analysis showed nu- cleotide changes in SV822/13, SV823/13 and SV1110/13 sequences that resulted in amino acid changes when compared with a standard CHV-1 sequence (GenBank accession: AF361074): SV822/13 - amino acid positions 35 (proline to alanine) and 199 (valine to leucine); SVs 823/13 and 242/14 - amino acid position 199 (valine to leucine) and SV1110/13 - amino acid position 36 (threonine to serine). Although most mutations in $\mathrm{gC}$ involved amino acid of similar chemical group and structure, the substitution of proline to alanine (SV822/13) rarely occurs and it might affect protein folding and/or function. The sequences were deposited in GenBank and named SV822/13 (gB - KJ676503, gC - KJ676504, gD - KJ676505), SV823/12 (gB - KJ676506, gC - KJ676507, gD - KJ676508), SV1110/13 (gB - KJ676509, gC - KJ676510, gD - KJ676511) and SV242/14 (gB - KJ946357, gC - KJ946358, gD - KJ946359). Unfortunately, the low number of sequences available in databases precludes further genetic and/or functional analysis of these glycoproteins.

The obtained $\mathrm{gC}$ sequences were then submitted to phylogenetic analysis using the Neighbor-Joining method with 2000 bootstrap replicates implemented by MEGA5.0 (Tamura et al. 2011), based on Tamura 3- parameters model (Figure 2). The phylogenetic three was constructed using CHV-1 sequences obtained from GenBank and Brazilian samples, such as SV453/08 - identified in a puppy infected with CHV-1 in Southern Brazil in 2008 (Oliveira et al. 2009) (Genbank accession - KJ676501).

The presumptive diagnosis of the four events was based on the clinical signs, high mortality and pathological findings. At necropsy, the macroscopic features were typical of neonatal CHV-1 infection, characterized by a multisystemic necrohemorrhagic disease (Decaro et al. 2008, Oliveira et al. 2009). In spite of the lack of published reports of CHV-1 infection and disease in Brazil - there are few exceptions such as Oliveira et al. (2009), Ávila et al. (2011) and Kurissio et al. (2012) - veterinarians frequently report cases compatible with CHV-1-induced disease. Virtually all suspected cases, however, remain without a definitive etiological (virology, serology, molecular) diagnosis. In these particular cases, however, the support of a virology diagnostic laboratory allowed a definitive etiological diagnosis. Positive virus isolation in primary canine cells, PCR and nucleotide sequencing confirmed the presumptive diagnosis. Subsequently, serology confirmed the circulation of the virus in the affected kennel.

Neonatal mortality in puppies is frequently reported during autumn and winter, when the environmental temperatures fluctuate from 0 to $+10-15^{\circ} \mathrm{C}$. In addition to environmental temperatures, housing conditions and the body temperature exert a strong effect on CHV-1 infection since optimal virus replication occurs at temperature below $35^{\circ} \mathrm{C}$ (Huxsoll \& Hemelt 1970). The disease is particularly severe and frequently fatal in young puppies in which the body temperatures are usually below $35-36^{\circ} \mathrm{C}$. The infection may be subclinical or mild in older dogs due to the ability of these animals to stabilize their body temperatures at $38^{\circ} \mathrm{C}$ (Jenson \& Ederstrom 1955).

In addition to the low body temperature, the lack of maternal immunity may worsen neonatal CHV-1 disease 
(Evermann et al. 2011). Maternal antibodies apparently protect puppies from fatal CHV-1 infection even though the animals develop subclinical infection (Decaro et al. 2008, Huxsoll \& Hemelt 1970). Thus, in a population of dogs in which the infection is endemic or can be frequently introduced, vaccination of females at heat and/or during pregnancy should be highly recommended to minimize the consequences of CHV-1 infection of puppies.

In the present report, the affected puppies presented severe respiratory signs that evolved to death in a day or so. Interestingly, a puppy from a French Bulldog litter (Case 3) also presented neurological signs, which are rarely observed in puppies naturally infected with CHV-1. For this reason, differential diagnosis for canine distemper virus (CDV), an agent involved in neurologic disease in dogs was performed (Tipold et al. 1992). Again, the pathological and virological findings were conclusive of CHV-1 infection and histopathological analyses dismissed CDV infection.

Sequence analysis of CHV-1 gC sequences (including those from the reported cases and two obtained in GenBank) revealed a high level of nucleotide identity. Nonetheless, SV822/13, SV242/14 and SV1110/13 isolates - all coming from the same kennel in different occasions - clustered in different branches. Two scenarios may be envisioned: i. the most likely hypothesis is that the viruses involved in these events have the same origin. The virus would remain latently in the dogs of the kennel and would be periodically reactivated and transmitted. The selective pressure upon the virus during the transmission-infection cycle would explain the few observed mutations. or ii. these viruses have different origins and have been introduced in the kennel population in different occasions. On the other hand, the closely relationship of $\mathrm{gC}$ among $\mathrm{CHV}$ - 1 samples from different Brazilian and world regions (SV822/13, SV435/08 and isolate Milou) confirms that $\mathrm{gC}$ is highly conserved and, therefore, is suitable for CHV-1 diagnosis and phylogenetic studies.

\section{CONCLUSIONS}

Veterinary clinicians frequently describe clinical cases compatible with CHV-1-induced disease; but etiologic confirmation has been accomplished in rare occasions.

In this sense, this report contributes for the identification and awareness of a common cause of neonatal deaths in puppies in Southern Brazil, and indicates the need for the adoption of control measures, including vaccination.

Sources and manufacturers.- ${ }^{a}$ Life Technologies, CA, USA.

Declaration of conflicting interests.- The authors declared that they had no conflicts of interest with respect to their authorship or the publication of this article.
Acknowledgements.- This study was supported by Conselho Nacional de Desenvolvimento Científico e Tecnológico (CNPq). J.F. Cargnelutti, E.F. Flores and R. Weiblen are CNPq research fellows.

\section{REFERENCES}

Anvik J.O. 1991. Clinical considerations of canine herpesvirus-infection. Vet. Med-Us 86:394-395.

Ávila V.P.F., Esmeraldino A.T., Fallavena L.C.B., Césaro C., Rodrigues N.C., Braga A.C. \& Cerva C. 2011. Herpesvirus canino em filhotes da raça Golden Retriever - relato de caso. Clín. Vet. 92:52-56.

Decaro N., Martella V. \& Buonavoglia C. 2008. Canine adenoviruses and herpesvirus. Vet. Clin. North Am., Small. Anim. Pract. 38:799-814.

Evermann J.F., Ledbetter E.C. \& Maes R.K. 2011. Canine reproductive, respiratory, and ocular diseases due to canine herpesvirus. Vet. Clin. North. Am., Small. Anim. Pract. 41:1097-1120.

Hall T.A. 1999. BioEdit: a user-friendly biological sequence alignment editor and analysis program for Windows 95/98/NT. Nucleic Acids Symp. 41:95-98.

Hashimoto A., Hirai K., Suzuki Y. \& Fujimoto Y. 1983. Experimental transplacental transmission of canine herpesvirus in pregnant bitches during the 2 nd trimester of gestation. Am. J. Vet. Res. 44:610-614.

Huxsoll D.L. \& Hemelt I.E. 1970. Clinical observations of canine herpesvirus. J. Am. Vet. Med. Assoc. 156:1706-1713.

ICTV. International Committee on Taxonomy of Viruses. Virus Taxonomy: 2013 Release. <http://ictvonline.org/virusTaxonomy.asp> Acessed 20 February 2015.

Jenson C. \& Ederstrom H.E. 1955. Development of temperature regulation in the dog. Am. J. Physiol. 183:340-344.

Kurissio J.K., Cruz T.F., Linhares Araújo L.S. \& Araújo Jr J.P. 2012. Viral isolation and molecular identification of canine herpesvirus 1. Virus Reviews \& Research. <http://www.vrrjournal.org.br/index.php/vrrjournal/article/view/78/77> Acessed 23 June 2014.

Love D.N. \& Huxtable C.R. 1976. Naturally-occurring neonatal canine herpesvirus infection. Vet. Rec. 99:501-503.

Miyoshi M., Ishii Y., Takiguchi M., Takada A., Yasuda J., Hashimoto A., Okazaki K. \& Kida H. 1999. Detection of canine herpesvirus DNA in the ganglionic neurons and the lymph node lymphocytes of latently infected dogs. J. Vet. Med. Sci. 61:375-379.

Oliveira E.C., Sonne L., Bezerra P.S., Teixeira E.M., Dezengrini R., Pavarini S.P., Flores E.F. \& Driemeier D. 2009. Clinic and pathological findings in dogs naturally infected with canine herpesvirus. Pesq. Vet. Bras. 29:637642.

Ronsse V., Verstegen J., Onclin K., Farnir F. \& Poulet H. 2004. Risk factors and reproductive disorders associated with canine herpesvirus-1 (CHV1). Theriogenology 61:619-636.

Ronsse V., Verstegen J., Thiry E., Onclin K., Aeberle C., Brunet S. \& Poulet H. 2005. Canine herpesvirus-1 (CHV-1): clinical, serological and virological patterns in breeding colonies. Theriogenology 64:61-74.

Staden R. 1996. The Staden sequence analysis package. Mol. Biotechnol. 5:233-241.

Tamura K., Peterson D., Peterson N., Stecher G., Nei M. \& Kumar S. 2011. MEGA5: Molecular evolutionary genetics analysis using maximum likelihood, evolutionary distance and maximum parsimony methods. Mol. Biol. Evol. 28:2731-2739.

Tipold A., Vandevelde M. \& Jaggy A. 1992. Neurological manifestations of canine-distemper virus-infection. J. Small Anim. Pract. 33:466-470. 